\title{
To Make People With Dementia Forget About Forgetting: Experiences from a Daily Care Center
}

\author{
Oznur Korukcu ${ }^{1 *}$, Kamile Kukulu ${ }^{1}$ and Ismail Tufan ${ }^{2}$ \\ ${ }^{1}$ Akdeniz University, Faculty of Nursing, Department of Obstetrics and Gynecology Nursing, Turkey \\ ${ }^{2}$ Akdeniz University, Faculty of Literature, Department of Gerontology, Turkey
}

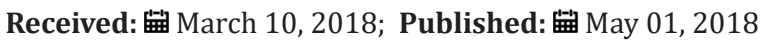

*Corresponding author: Oznur Korukcu, PhD, Akdeniz University, Faculty of Nursing, Department of Gynecology and Obstetrics Nursing, 07058, Antalya, Turkey

\section{Abstract}

Background: Characterized by progressive physical and cognitive dysfunction, Alzheimer's disease has some adverse effects on life quality of patients and their families.

Methods: This study held to determine the impact of the Blue House Alzheimer's Patients and Patient Relatives Center in life of mild Alzheimer's patients has a pattern of descriptive qualitative research. Eleven patients whose Standardized Mini Mental Test score is over 27 have been individually interviewed thoroughly. The data obtained as a result of the study has been transcribed and analyzed on interview outputs and the themes have been determined.

Results: It has been determined that the patients were feeling lonely and unhappy before they applied to the Blue House, but they started to feel better and made friendships because they went out of their home thanks to the Blue House. It is seen that the patients establish positive relationships with their friends, willingly join the activities and feel themselves valuable in the Blue House.

Conclusion: It can be said that the Blue House touches on the life of Alzheimer's patients and positively affect their health and wellbeing.

Keywords: Elderliness; Alzheimer's disease; Day care center; Blue house

\section{Introduction}

As a progressive neurodegenerative disease, Alzheimer's is the primary disorder caused by this process and today's modern medicine is continuously seeking a remedy [1,2]. Alzheimer's is a kind of neurological disease making the person diverge firstly from immediate surroundings, them from him/herself step by step and the memories about the current life are becoming indistinct one by one, eventually the person has difficulty even in knowing him/herself [3]. Alzheimer's disease is a process required to be addressed carefully because it brings along a number of symptoms which reduce patients' quality of living [2,3]. Progressive impairment of memory function is one of the most basic symptoms of this disease and forgetfulness may have some destructive effects on individuals particularly during the mild phase [4,5]. Even though pharmacological therapy slows down progression of the disease in early period, the lack of a definite treatment significantly affects both the individual who suffers from the disease and his/her family $[6,7]$. As one of the frightening returns of elderliness, Alzheimer's disease means the beginning of a self-sacrificing process for patient relatives and caregivers [4,5]. Characterized by progressive physical and cognitive dysfunction, Alzheimer's disease has some adverse effects on life quality of patients and their families [8]. All kinds of efforts aiming to increase the quality of living in patients and patient relatives who struggle with destructive effects of Alzheimer's disease are highly valuable. This study is conducted to determine the impact of the Blue House Alzheimer's Patients and Patient Relatives Center (the Blue House) that aims to meet the requirements of patients and their families by touching on their life. 
The blue house alzheimer's patients and patient relatives center

The Blue House Alzheimer's Patients and Patient Relatives Center was opened by cooperation of Antalya Metropolitan Municipality and National Social Applied Gerontology Association in order to meet care requirements of Alzheimer's patients, increase quality of living in patients and patient relatives and improve their interaction with each other. Care is provided for Alzheimer's patients in the first and second phase and patient relatives in the Blue House Alzheimer's Patients and Patient Relatives Center. The Blue House has been designed as a modern facility that enables satisfaction of care requirements of Alzheimer's patients and meeting, information and experience sharing for families. Located on a place where the sea and nature intersects, the Blue House incorporates all kinds of possibilities by which the patients may satisfy their basic needs. A team composed of a social service expert, a nurse, a gerontologist, a psychologist, caregiver nurse, a physiotherapist, nutritionist, cook, security and cleaning staff is operating at the center. All the services provided at the center are free of charge. One of the most significant services is free transport of patients to the center. At the center where some group activities including paint, brain boosting games, hiking, yoga, meditation, singing are performed. The total of 55 Alzheimer's patients in total including 30 patients that have mild level and 25 patients that have medium level are provided care at the center.

\section{Materials and Methods}

\section{Data gathering process}

The data has been collected by face to face interviews with a semi structured interview form created by the researcher in direction of the study objectives. Once it has been specified by the gerontologist that the patients have clearer perceptions and are more willing to talk after the activities, the patients are interviewed after the activities held at the center. Any sample restriction was not applied in the study, 27 patients who have a Standardized Mini Mental Test score over 27 and 11 patients who are volunteer in participating the study have been interviewed thoroughly. The data obtained as a result of the study has been transcribed and analyzed on interview outputs and the themes have been determined. The interview has been started with the question "Can you please tell me what is ageing in your opinion?" The other interview questions include "How do you spend most of your time in the Blue House?", "How do you feel by staying at the Blue House?", "Do you think the Blue House resulted in some significant changes in your life?", "How did taking care at the Blue House affect your life?"

\section{Participants and setting}

The research held in qualitative pattern was conducted with 11 mild level Alzheimer's patients who are provided care at the Blue House between April $19^{\text {th }}$ and $21^{\text {st }}$ of 2017 . Elderly patients who have a Standardized Mini Mental Test score over 27, has been diagnosed mild level Alzheimer's and are volunteer in participating the study have been included in the study. A profile of the participants is shown in Table 1.

Table 1: Characteristics of participants.

\begin{tabular}{|c|c|c|}
\hline Characteristic & \multicolumn{2}{|c|}{ Mean \pm SD } \\
\hline Age & \multicolumn{2}{|c|}{$76.09 \pm 6.5$} \\
\hline Number of children & \multicolumn{2}{|c|}{$2.45 \pm 0.8$} \\
\hline Characteristics & $\mathbf{n}$ & $\%$ \\
\hline \multicolumn{3}{|l|}{ Sex } \\
\hline Female & 6 & 54.5 \\
\hline Male & 5 & 45.5 \\
\hline \multicolumn{3}{|l|}{ Education status } \\
\hline Illiterate & 1 & 9.1 \\
\hline Literate & 3 & 27.3 \\
\hline Primary school & 5 & 45.5 \\
\hline High school & 1 & 9.1 \\
\hline $\begin{array}{l}\text { Undergraduate/ } \\
\text { Postgraduate }\end{array}$ & 1 & 9.1 \\
\hline \multicolumn{3}{|l|}{ Occupation } \\
\hline Farmer & 2 & 18.2 \\
\hline Retired civil servant & 3 & 27.2 \\
\hline Carpenter & 1 & 9.1 \\
\hline Tailor & 1 & 9.1 \\
\hline Housewife & 4 & 36.4 \\
\hline \multicolumn{3}{|l|}{ They live with } \\
\hline Alone & 2 & 18.2 \\
\hline Spouse & 2 & 18.2 \\
\hline Children & 6 & 54.5 \\
\hline Caregiver & 1 & 9.1 \\
\hline
\end{tabular}

\section{Validity and reliability}

Validity implies accuracy of scientific findings and reliability implies repeatability of scientific findings in qualitative researches [9]. In this direction, the researcher avoided from behaving as a leader during the observation and interview process and from bringing in his/her subjective judgments during the data gathering process. An interview form has been created in order to increase internal validity (conclusiveness) of the research and a conceptual framework has been constituted about the subject as a consequence of literature review on the corresponding field. The research data has been recorded and the themes have been repeated by the assistant researcher. The themes of two researchers have been compared and integrity has been ensured. The correlation between the themes and sub-themes which constitute the themes and the correlation of each theme with others have been determined in the content analysis. All the findings have been reported directly without making any interpretation to improve internal reliability (consistency) of the research.

\section{Ethical dimension of the research}

The permission has been obtained from the director of the Blue House before starting the research. The ethics committee 
approval has been obtained from Akdeniz University Faculty of Medicine Clinical Researches Ethical Committee (Approval No: 70904504/261). Mild level Alzheimer's patients to participate in the study have been informed about the study and then their written and oral consent has been received. The study has no risks on the participants.

\section{Results}

The research results have been presented fewer than three chapters. The first chapter addresses to the subject of being an Alzheimer's patient, the second addresses to Life in the Blue House and the last chapter addresses to the Impact of the Blue House on Alzheimer's Patients. Each chapter has its own themes. Some themes have sub-themes.

\section{Chapter 1: Being an alzheimer's patient}

\section{Theme 1: I get older if I forget}

Most of the participants specified that forgetfulness is a sign of elderliness. One patient said working hard results in elderliness, another one stated that he/she has the tendency of living longer genetically and tries to overcome forgetfulness. It has never come to my mind that someday I would become such forgetful People become forgetful when they get older. (78 year's old, female). Someone who works hard tends to forget. Someone who forgets tends to get older. Everything is in turn in life. I realized when I started to forget, it's my turn. Forgetting (he hesitated)... Forgetting means getting older. (81 year's old, male). Sometimes some blanks are happening on my mind but I do my best to avoid from forgetting. (71 year's old, male). One participant stated that forgetfulness affects her interaction and her sharing decreased with her immediate neighboring.

I am no longer the person I had been 30 years ago. I cannot do anything, any little thing (she waited for 5 seconds) as I did in the past. My memory is not as good as it was in the past. I always forget where I have put my stuff. Anyone does not tell me anything, not want to talk to me. They say you will forget anyway when I feel sorry. (92 year's old, female).

Theme 2: I wish there were nothing called as elderliness

It has been established that some participants of the study have positive health perceptions while some others have negative perceptions. Majority of the participants told that the most important problem they suffer has become forgetfulness after they were diagnosed with Alzheimer's. My illness started once I forgot my daughter's name. Actually, there is nothing wrong with me; I am sound as a barrel. The time has passed by working, engaging in carpentry. Now I can't remember names of people. (72 year's old, male). One of the participants told that her health is good; he has just difficulty in using electronic appliances. I can't use electronic appliances. My grandchildren teach me how to use a mobile phone, but I fail lastingly. I forget immediately. ( 80 year's old, male). It is established that female participants who have the capability to do daily activities have positive health perceptions. Actually there is nothing wrong with me. I can do all my work by myself. I just have some kinds of forgetfulness time to time. I can't remember where I had put my stuff occasionally (75 year's old, female). I can do every work. Cooking, cleaning, ironing... I can do all my work by myself. Thank goodness I am healthy (70 year's old, female).

On the other hand, women who cannot do daily activities by their own have negative health perceptions. It is established that female patients who cannot fulfill the role of caregiver at home feel troubled for the fact that they currently cannot do housework they had done in the past and they feel they impose themselves on their children. Elderliness is very difficult. I wish there is nothing called elderliness. Sometimes I say death might be better. My health is bad. I feel I am a burden on my children. I feel myself dysfunctional. I wish I had died when I was young. (78 year's old, female). I was doing all housework myself in the past. I had completed all the works until my daughter come from work. Now I can do nothing. My daughter is engaging in everything. I feel myself as a redundancy. (73 year's old, female).

\section{Theme 3: Loneliness}

When the lives of participants before they came to the Blue House are questioned, it is established that almost all of them felt loneliness before applying to the Blue House. A patient who was living alone told that he/she accompanies with the flowers on his/ her garden, those who were living with their children stated that they were alone when their children go to work. Do you mind if someone is afraid of her home? I started to be afraid of my home. I was staying alone at home when the children went to work. I adopted loneliness as my destiny. Loneliness is very difficult; I thought that I might die myself. (73 year's old, female). When my children went to work I was waiting for their return in the past. I was alone at home. I was not strong enough to go out, I was feeling disinclined to go out. I was not even visiting my neighbors. (70 year's old, female). Some of the participants told that they were thinking about their past when they stand alone, thinking about the past all the time make them upset.

I was standing all alone at home and waiting for my daughter's return from work in the past. Being alone is very difficult. I become very thoughtful when I have nothing to do. Everyone misses the past. But the past does not come back when you think about it (he filled with tears). (75 year's old, male). I was in bed all day long before I came here. I had a knee surgery and I have prosthesis. I can't do any housework. I was thinking about the past all day long. About how I became such unable... I was crying whenever I remember the past. Time is not going on when you are alone at home. But you can even forget about your misery in crowd (78 years old, female).

\section{Chapter 2: Life in the blue house}

Theme 1: I could go out from home

Most of the participants stated that they like the location and spatial characteristics of the Blue House. It is seen that having care in the Blue House makes the patients happy. I was in bed all day 
long and never went out normally. Now I could go out from home. We do not have a car; no one could take me to here. The Blue House staff picks me up here. I love the garden of this place, I enjoy here. I think we are in the best place of Antalya now. (78 year's old, female). I did not believe if someone told me I might receive service from such a place when I was young. I was grown up in a village. I have never seen such places. I got so excited when I first came here. I am so happy for being admitted here. I love this place so much. (70 year's old, female).

Theme 2: I love my friends so much

It is seen that the Blue House strengthens bonds of friendship and increases interaction between the patients.

I have friends to share my life here. I love all them so much. The greatest favor of this place is to make me have friends. We are entrusted by each other. We talk together and advice each other. (71 year's old, female)

I even do not think about my children while I have a conversation with my friends (71 year's old, male). We pay attention to get along with our friends. No one hurts others, we love each other. I forgot about my own misery when I see other friends here. (72 year's old, male). One of the participants stated that she loves her friends in the Blue House so much and she misses them when she does not see, another one told that she forgot to focus on the past in crowd. The best characteristic of here is to have friends. I love them and miss when I don't see. I forgot to think about the past when I am in crown. (78 year's old, female).

\section{Theme 3: Forget about forgetting}

The elderly patients included in the study told that they joined some activities like yoga, hiking, painting, singing in the Blue House. They stated that they enjoy the Blue House activities and the time is going on fast here. We always engage in something. I never get bored here. They measure our tension when we come first in the morning. Then they serve us tea. We sing, we paint. We have lunch. We have conversation with our friends. Time is going on fast here (78 year's old, female). Coming here is enjoyable for us. We spend good time here. (75 year's old, female). The participants told that forgetfulness as one of the biggest problems stops being a problem in the Blue House, because they have no time to forget here. This place made me forget about forgetting. We are such busy here that it seems like we have no time to forget. We do many things; I can't remember all of them now. But I am having fun while doing yoga at the most. A Japanese yoga instructor is coming for us. She does not speak Turkish well. She can't say Turkish words right. Let me show you how to do yoga (doing yoga while laughing) (71 year's old, male). We are doing something all the time. There is no time remained to forget. We are always busy. (75 year's old, male).

Chapter 3: The impact of the blue house on Alzheimer's patients

Theme 1: I am so happy here

All the participants stated that they are glad to receive care in the Blue House. I am so happy here. This place is better than home.
I like this place more than home. I am afraid of the possibility that they say you will not come here anymore (73 year's old, female). I take please in coming here. I get ready early morning and wait for them to come get me. I was alone before the Blue House, I was crying so much. I am not unhappy anymore. The God predestinated us to come here, I am praising all the time. I think this place is an award to me (78 year's old, female). I come to the Blue House every day of a week. Only Sunday is holiday and I fall into a loss during Sunday. Even just Sunday is going on hard at home (70 year's old, female).

Theme 2: I started to feel that I have become useful now

It is seen that Alzheimer's patients try to help each other, and their interaction makes them feel better. I started to feel that I have become useful after I started to come to the Blue House. I talk to my friends and help them. I feel better here compare to my situation at home. (81 year's old, male). I support other friends to be good like me. I try to convince those who do not want to walk. My father died when he was 107 years old. I tell my friends about the father. (71 year's old, male)

\section{Discussion}

Neurodegenerative changes are characterized by reduction in cognitive abilities and memory loss in elderly individuals. There is no effective treatment to resolve the problem of forgetfulness in Alzheimer's patients yet, so patients and patient relatives encounter with difficult situations by reason of forgetfulness at the most [10]. It is specified that progressive reduction in memory function is one of the most destructive situations for mild level Alzheimer's patients [5]. Most of the participants also stated that the most important problem they suffer is forgetfulness after they are diagnosed with Alzheimer's in the current study. Seidl et al. [11] determined that gradual weakening of memory that constitutes the personality of individuals affects the wellbeing of patients in Alzheirmer's disease. Our study establishes that forgetfulness affects the interaction of Alzheimer's patients with their immediate neighboring.

Bahar-Fuchs et al. [12] states that some depressive symptoms appear in early periods of Alzheimer's disease. The experience of forgetfulness, when associated with depression, may bring along an extra burden particularly for patient relatives [13]. This study finds that the diagnosis of Alzheimer isolates patients; particularly patients whose self-care requirements are met by their children feel themselves useless. Health perceptions of female patients who cannot do their housework they previously did and are in need of their children help are much worse than those who can do housework by their own. Even some patients stated that they feel themselves as a redundancy and they would prefer to die rather than experiencing these days. It is believed that this situation distinguishes because of domestic role of women in Turkish society. The situation that the mother who satisfies all care requirements of family members and undertakes the responsibility of all housework alone like cooking, cleaning, washing etc. [14] turns into a position of receiving care from the role of the main caregiver in the family by reason of Alzheimer's disease negatively affects the patients. 
It is stated that improvement in feelings like personal control, social skills, self-confidence and optimism will increase quality of living in Alzheimer's patients [15]. It is expressed that improvement in social and cognitive interactions with their neighboring improve wellbeing and health status of patients [15,16]. This study establishes that receiving care in the Blue House decreases the level of loneliness and increases their mutual interactions and level of happiness in patients similar to the literature.

\section{Acknowledgmen}

The authors would like to thank the participants for their time.

\section{Reference}

1. Frank L, Howard K, Jones R, Lacey L (2010) A qualitative assessment of the concept of dependence in Alzheimer's disease. Am J Alzheimers Dis Other Demen 25(3): 239-247.

2. Kahle WK, Ye W, Henley D, Hake AM (2016) Assessing quality of life in Alzheimer's disease: Implications for clinical trials. Alzheimers Dement 6: 82-90.

3. Barbe C, Morrone I, Novella JL, Drame W, Wolak A, et al. (2016) Predictive Factors of Rapid Cognitive Decline in Patients with Alzheimer Disease. Dement Geriatric Cogn Dis Extra 6(3): 549-558.

4. Silva AR, Pinho MS, Macedo L, Moilin C, Caldeira S, et al. (2017) It is not only memory: effects of sensecam on improving well-being in patients with mild alzheimer disease. Int Psychogeriatr 29(5): 741-754.

5. Jahn H (2013) Memory loss in Alzheimer's disease. Dialogues Clin Neurosci 15(4): 445-454

6. Steeman E, Casterlé D, Dierckx B, Godderis J, Grypdonck M (2006) Living with early-stage dementia: A review of qualitative studies. J Adv Nurs 54(6): 722-738.
7. Hattori H, Hattori C, Hokao C, Mizushima K, Mase T (2011) Controlled study on the cognitive and psychological effect of coloring and drawing in mild Alzheimer's disease patients. Geriatr Gerontol Int 11(4): 431437.

8. Zucchella C, Bartolo M, Bernini S, Picascia M, Sinforiani E (2015) Quality of life in Alzheimer disease: a comparison of patients' and caregivers' points of view. Alzheimer Dis Assoc Disord 29(1): 50-54.

9. Baxter P, Jack S (2008) Qualitative case study methodology: Study design and implementation for novice researchers. The Qualitative Report 13(4): 544-559.

10. Geyer J, Insel P, Farzin F, Sternberg D, Hardy JL, et al. (2015) Evidence for age-associated cognitive decline from Internet game scores. Alzheimers Dement 1(2): 260-267.

11. Seidl U, Lueken U, Thomann PA, Geider J, Schröder J (2011) Autobiographical memory deficits in alzheimer's disease. J Alzheimers Dis 27(3): $567-574$

12. Bahar FA, Clare L, Woods B (2013) Cognitive training and cognitive rehabilitation for mild to moderate Alzheimer's disease and vascular dementia. Cochrane Database Syst Rev 6: 1-100.

13. Baquero M, Martín N (2015) Depressive symptoms in neurodegenerative diseases. World J Clin Cases 3(8): 682-693.

14. Körükcü Ö, Kayır GÖ, Kukulu K (2012) Partnership with men for elimination of violence against women. Current Approaches in Psychiatry 4: 396-413.

15. Steptoe A, Wardle J (2017) Life skills, wealth, health, and wellbeing in later life. Proceedings of the National Academy of Sciences 114: 43544359.

16. Zaninotto P, Wardle J, Steptoe A (2016) Sustained enjoyment of life and mortality at older ages: Analysis of the English longitudinal study of ageing. BMJ 355: 62-67.

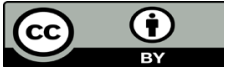

This work is licensed under Creative Commons Attribution 4.0 License

To Submit Your Article Click Here:

Submit Article

DOI: 10.32474/LOJNHC.2018.01.000107

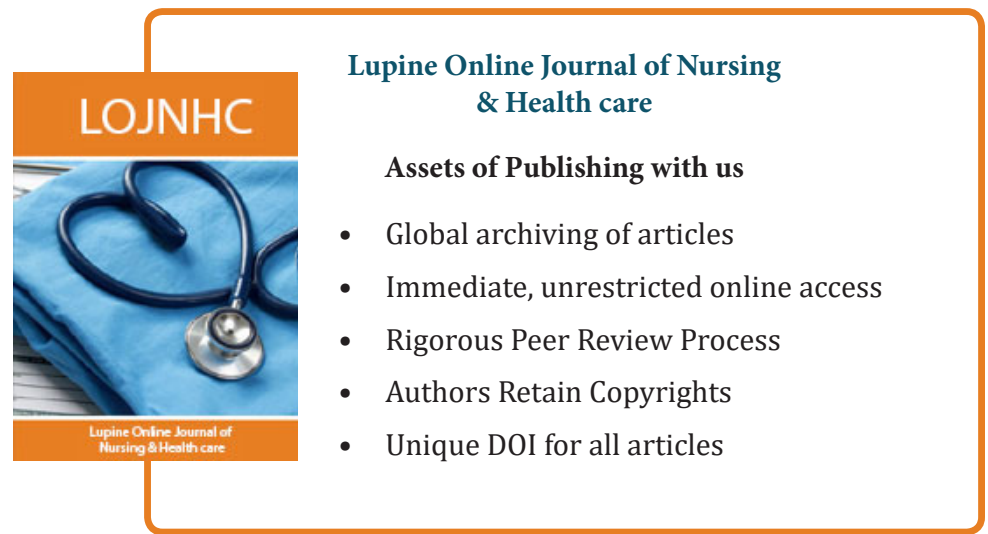

